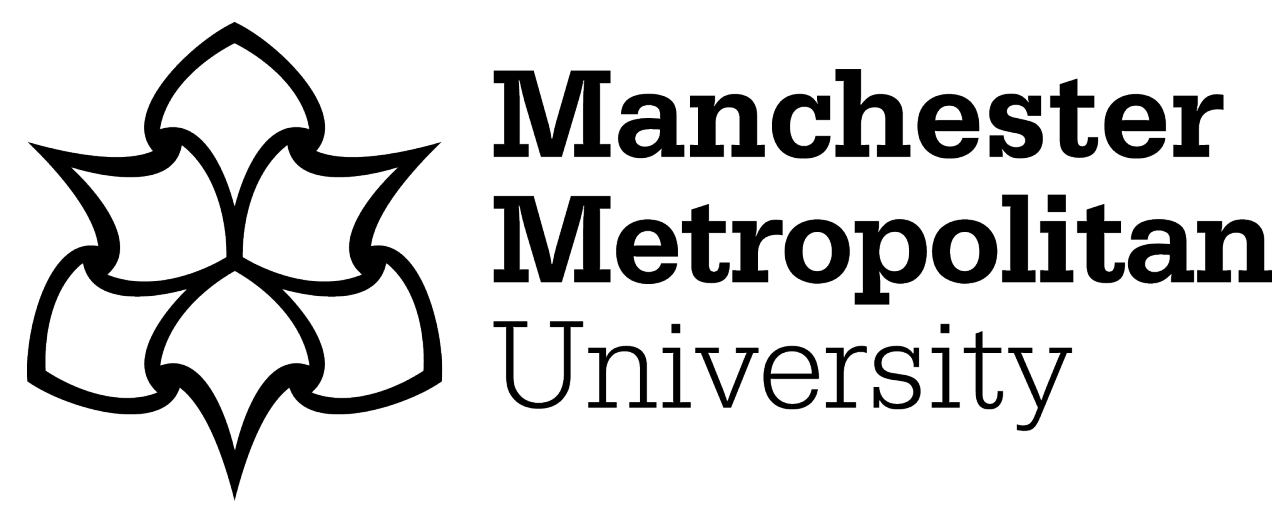

Raj, Senthorun ORCID logoORCID: https://orcid.org/0000-0001-6972-9252 (2018) Once more with feeling: queer activist legal scholarship and jurisprudence. The International Journal of Human Rights, 24 (1). pp. 62-79. ISSN 1364-2987

Downloaded from: https://e-space.mmu.ac.uk/628636/

Version: Accepted Version

Publisher: Informa UK Limited

DOI: https://doi.org/10.1080/13642987.2018.1513402

Usage rights: Creative Commons: Attribution-Noncommercial 4.0

Please cite the published version 


\title{
Once more with feeling: queer activist legal scholarship and jurisprudence
}

\author{
Senthorun Raj \\ School of Law, Keele University, Staffordshire, UK
}

\begin{abstract}
Scholars and activists concerned with eliminating violence and discrimination against lesbian, gay, bisexual, transgender, and intersex (LGBTI) people have generated passionate conversations about pursuing law reform to make injuries, intimacies, and identities visible while challenging how legal systems continue to marginalise queers. My paper contributes to these conversations by using emotion as an analytic register to navigate the ways case law seeks to 'progress' the intimacies and identities of LGBTI people from positions of injury. In doing so, I introduce a new approach to queer activist legal scholarship by reading emotion in law on two levels: I target its enactment in what I call 'pro-LGBTI cases' and it forms the register in which I pursue my evaluation of those cases. Rather than develop this analysis around specific doctrines or jurisdictions, I create my own activist-scholarly narrative by reading emotions through their enactments in proLGBTI cases that cross various sub-disciplines of law. From hate crime laws to marriage equality cases, this paper navigates competing emotions, such as hate and love, which simultaneously structure legal progress. Reading emotion enables us to address how legal recognition and visibility can work, paradoxically, to cover the queer injuries, intimacies, and identities they seek to address.
\end{abstract}

\section{KEYWORDS}

Queer; emotion; law; LGBTI; activism

\section{Introduction}

Movements for justice and equality generate emotion, particularly among those who participate in them. For many activists and scholars, justice and equality involve a turn to the law. Law is (or is at least seen to be) a space in which minorities can claim what is 'just'. Such justness is rarely disembodied - it is often attributed to a sense of feeling (such as vindication or satisfaction) on the part of those who have been victimised. For minorities who occupy positions of potential vulnerability, whether on the basis of our sexual orientation or gender identity, it is not difficult to see and feel the emotions that arise in activism and scholarship when law reform is heralded as a means to remedy homophobic and transphobic injuries such as inequality, discrimination, and violence. This paper takes up some of the emotional dimensions of queer legal progress to expand the scope of queer activist legal scholarship. I develop this analysis by exploring how contemporary 
hate crime and marriage equality cases in the United States (US) enact emotion to address homophobic and transphobic injuries that limit the expression of queer intimacies and identities.

I begin this paper by outlining activist and scholarly responses to progress made by sexual and gender minorities in recent years. Specifically, I note the ways in which queer activist legal scholars define the terms of legal progress and how emotion, while present, has been obscured as both a framework and object of analysis in these discussions. I then offer two contributions to furthering queer activist legal scholarship in the area of lesbian, gay, bisexual, transgender, and intersex (LGBTI) human rights. First, I situate what I mean by 'pro-LGBTI cases' - a category that includes case law that is held out by activists and scholars as a sign of legal progress for sexual and gender minorities. Second, I discuss how to 'read emotion' in this jurisprudence and why a queer reading of law using emotion enables us, as activist-scholars working in law, to evaluate the nature of 'progress' made possible by law. In the latter parts of the paper, I develop these affective contributions to queer activist legal scholarship by exploring how competing emotions, such as hate and love, structure socio-legal claims of progress in US hate crime and marriage equality cases.

\section{Que(e)rying activist legal scholarship}

Drawing from rich traditions in critical legal studies, I define 'activist legal scholarship' as intellectual inquiries aimed at exposing the ways in which legal systems oppress minorities and providing critiques and/or prescriptions for remedying such injustices. ${ }^{1}$ There are multiple forms of such activist legal scholarship, which are beyond the scope of this paper. In this section, I focus my inquiry on how the demands of legal activism and scholarly inquiry can come into tension. As Frank Munger observes, this tension manifests when the call of legal activism to pursue forms of action (such as law reform) that address pressing human rights abuses brushes against the call of scholarship that leads to pursuing intellectual curiosities and undesirable questions that may require suspensions of moral judgement. ${ }^{2}$

LGBTI law reforms reflect this tension through the emotional push by queers to be 'seen'. Over the last 50 years, feelings such as despair, anger, hope, and happiness (to name just a few) have animated activist, academic, and advocacy debates over the capacity of law to recognise homophobic injuries, queer intimacies, and sexual identities. Courts, as arenas for LGBTI individuals to challenge the legality of various forms of institutional discrimination, have been increasingly important for individuals wishing to vindicate their human rights. ${ }^{3}$ For legal scholars interested in, and motivated by concerns for, the wellbeing of minorities in social and legal contexts, academic inquiry has been directed at recognising and addressing how jurisprudence poses problems and promises progress. ${ }^{4}$

In demands for social justice, equality-minded socio-legal scholars have regarded progressive judgments ushering in law reform as positive outcomes, given the enormous purchase they have in society. For example, Yvonne Zylan argues that reforms directed at sexual or gender minorities not only confer legal recognition but also symbolise increased (public) acceptance of LGBTI visibility. ${ }^{5}$ Reflecting an instrumentalist idea of the relationship between law and social change, Chris Ashford suggests that statutes and case law provide an easily discernible benchmark for measuring the progress made towards 
recognising sexual minorities and exposing what remains to be done. ${ }^{6}$ These and other scholars have cast legal reforms as markers on a metaphorical ruler of social justice markers that we still use to measure, and ultimately feel, the changes that have taken place in society.

Progressive jurisprudence, however, operates as a paradox: it can represent the interests of those who are 'disempowered' but only by limiting the terms of representation. Rather than pursuing abstract rights claims, Lisa Bower advocates a 'direct address' to the courts one that refuses static representations or legal language to shape new modes of recognition. ${ }^{7}$ Ruthann Robson notes that 'context is a dominant consideration' in any understanding of how judicial review operates. ${ }^{8}$ I would add that understanding judicial reasoning in progressive cases requires more than a contextual consideration of what shapes changing legal norms. ${ }^{9}$ John Fisher argues that queer cases require 'queer contextualisation'. ${ }^{10}$ He pursues this strategy within a discussion of 'substantive equality' - a form of recognition that seeks to remedy socio-historical inequalities contributing to sexual minority marginalisation. ${ }^{11}$ These scholars make visible the importance of parsing progressive legal claims through a queer critique of existing social norms.

Moreover, queer legal scholars have drawn attention to how legal violence (which includes punitive laws, administrative burdens, and ethnocentric representations of sexuality) has become justified in the pursuit of progressive legal projects. ${ }^{12}$ As Marc Spindelman suggests, we should be cautious of using a homophobic legal system to remedy homophobic harms. ${ }^{13}$ Queer sexual freedom cannot be sourced within the moral economy of the law - it develops in its 'shadow. ${ }^{14}$ Law reform privileges assimilation into an existing legal 'discipline', rather than contesting the institutional violence that such orders produce. ${ }^{15}$

Such a dynamic treatment of legal interventions raises the complex relationship law has to both individual and institutional concerns of advancing justice for LGBTI minorities. In order to navigate the limits of legal progress, I want to 'queer' the affective recognition of injury, intimacy, and identity. I use queer as a critical theoretical tool alongside my analysis of emotion (outlined below) to draw out the discomfort, resistance, transition, and trouble in cases that seek to progress sexual and gender minorities from a position of injury and to enable their intimacies and identities. ${ }^{16}$ As activist legal scholars, this analysis allows us to deconstruct emotional enactments of progressive cases by troubling the socio-legal norms of injury, intimacy, and identity they shape. Yet, as Aleardo Zanghellini observes, queer is not limited to deconstruction or antinormativity. The appeal of using queer theory to read emotion in jurisprudence, then, lies in the normative, political commitments for justice that this queer reading can affirm. ${ }^{17}$ In foregrounding these commitments, I want to urge those engaged in legal activism (such as judicial review and statutory reform) and critical legal scholarship (such as critical writing about law reform and legal rights) about queer minorities to recognise how emotion shapes specific legal claims and use emotion as a methodological lens to navigate the reach of legal progress aimed at supporting LGBTI people.

As queer activist legal scholars seeking to simultaneously navigate demands for deconstruction and affirmation, we need a theoretical framework to evaluate claims of state recognition in relation to queer minorities. ${ }^{18}$ I attempt to provide this by combining the use of queer as a critical mode of analysis with the category of 'pro-LGBTI cases' to offer an analytic lens for activist-scholars working within legal institutions, particularly those engaged 
with judicial review, to register the ways in which jurisprudence remedies queer injuries and enable intimacies and identities. As such, my references to pro-LGBTI cases are not meant to be exhaustive or doctrinally self-contained. Indeed, 'LGBTI' is an activist label that is culturally contingent. ${ }^{19}$ I adopt the more inclusive label of proLGBTI rather than 'pro-gay' here because the cases discussed in this paper have doctrinal implications for bisexual, lesbian, trans or gender-nonconforming, and intersex minorities. I focus on judgments here because they are data that evince the ways law reform goals, statutes, precedents, and parties come into contact. ${ }^{20}$ They enable us to see the embodiment of law in both specific terms (the remedies for particular parties) and general terms (the precedents they establish and the social norms they express). I collate these cases on the basis of activist legal scholars having celebrated them as progressive in the pursuit of visibility and equality. Yet, this collation follows a queer call to move against 'proper objects'. ${ }^{21}$ Rather than 'properly' focus on judgments as a set of doctrines or style of legal writing within a specific jurisdiction, I look at how and why we should read pro-LGBTI cases in a (queer) register of emotion. In cases designed to progress the human rights of LGBTI minorities, judicial decisions do not only have to engage with the emotions that animate LGBTI individuals seeking progress, they also distil these emotions through the text of judgments that activist legal scholars subsequently hail as progressive.

\section{Reading emotion}

In writing about emotional enactments in pro-LGBTI cases, activist scholars must first recognise how our scholarship is a product of them as well. Pain, disgust, hate, anger, fear, and happiness have underpinned my own encounters, as an activist legal scholar, with the judicial texts that form my queer catalogue of case studies. It is important to position my own emotional investment in pro-LGBTI cases because, as a queer individual, I subscribe to the hope that legal progress will remedy experiences of injury and my intimacy and identity will be given greater support as a consequence of recognition. Yet, such emotional investments, as outlined below, can fail to address systemic queer subordination. In Object Lessons, Robyn Wiegman observes, 'identity knowledges are animated by powerful political desires'. ${ }^{22}$ Such disciplinary logics are informed by the desire to reveal the way in which norms and dominant knowledge systems shape particular objects of inquiry (in my case, jurisprudence). Like all activist scholars, it is difficult to separate my investments in particular emotions from investments that reveal the emotions that form the object of my scholarly inquiry. My own desires for justice animated this critical inquiry. Rather than eschew such desires, I have chosen to give effect to them by pursuing a reading of emotion at the intersections of law and queerness in order to contribute greater insights into how ideas of injury, intimacy, and identity are shaped in the pro-LGBTI cases that I bring together. While I do not labour over personal emotions that arise, as I read pro-LGBTI hate crime and marriage equality cases in the sections below, I want to preface that reading emotion is an emotional process. It is a process that generates an array of, and sometimes contradictory, emotional responses from the activist-scholar reader. Personal emotions inevitably shape how I organise and analyse the following cases. I offer this as a caution, then, against attempts to turn the queer analysis of emotion in law I offer into a disembodied or abstracted methodology. 
Contributing to an activist legal scholarly community motivated by disparate emotions for social justice involves moving beyond legal scholarship that diagnoses individual doctrines or focuses on institutional reform. In a provocative article titled 'On Writing Dangerously', Fleur Johns articulates the need to engage in forms of legal research that interrupt the demand for 'real world' solutions. ${ }^{23}$ In a changing world, law is often invoked at moments of crisis that generate impulses for regulation. Legal scholars often arrive at such crises with a 'problem-solving' mentality that imagines the problem as something external to the legal academic. ${ }^{24}$ Framing legal research in this way, however, discourages more reflexive and adaptive legal analysis that addresses the orientations, attachments, and complicities that researchers have within legal institutions. Pursuing this sort of analysis, in the activist legal scholarship I wish to develop, requires a queer focus on what it means to pursue progressive, activist legal analysis. Ambivalence and hesitation in activist movements engender their own risks (such as delaying legislative or policy responses to anti-LGBTI violence or discrimination) - this is precisely why such writing is dangerous. ${ }^{25}$ As activist legal scholars, however, we must pursue legal agendas for social change while emotionally reflecting on what is at stake in the socio-legal claims we make.

Emotion circulates ubiquitously in law: from the emotional states of parties, to the gut reactions of juries or legal scholars, to passionate legislative debates. In thinking about emotion, rendering it into an object of scholarly inquiry, we seek to see what we (or others) feel. ${ }^{26}$ My use of emotion, however, does not seek to claim sense of the feelings of litigants, lawyers, and judges, nor do I try to diagnose the feelings of legal actors or institutions. My reading sits in contradistinction to other law and emotion scholarship; it does not pursue an analysis of emotion as a personal experience, social cultivation, and/or psychological process. $^{27}$

Bearing this in mind, I have chosen to develop a queer reading of emotion that looks at it as a textual enactment of judicial decisions. I situate 'law' here as a field that exhibits literary or narrative tendencies. As James Boyd White argues, law is a disciplinary terrain generated through disparate narrative acts that include legislative enactments, litigation, testimony, and judicial pronouncements. ${ }^{28}$ These acts develop a 'textual community' through officially designated actors such as lawyers, judges, and legislators working in official institutions such as courts, tribunals, and parliaments. My reason for attending to emotion and law in terms of case law's textual properties is that conversations about emotion in law tend to focus on the emotions of parties or the phenomenological experiences of judges, rather than exploring how emotion assumes legal significance through embodiment in judicial texts. ${ }^{29}$ Activist legal scholars concerned with LGBTI minorities must take account of emotion at this level - to address the legal politics of emotion because these decisions function as both social and legal measures of queer injury, intimacy, and identity.

My argument focuses on the performative dimensions of emotion, and the insights gained from this focus allow me to problematise how emotions shape (hetero)normative ideas of queer identity, intimacy, and injury in the pursuit of legal progress. I develop a queer reading of jurisprudence, as an activist legal scholar, by foregrounding emotions instead of doctrines in order to rethink the claims of progress articulated through such emotions. Eve Sedgwick describes the sort of reading strategy I adopt as an 'affect theory'. Such a theory is 'queer' because it relies on 'selective scanning' and 'amplification' 
in order to resist normative scholarly tendencies to aggregate or taxonomise so as to 'prove' an object (such as injury, intimacy, or identity) of thought conclusively. ${ }^{30}$ I transpose Sedgwick's call to loosen the need for diagnostic analysis in favour of amplifying emotion when selectively reading how it emerges in pro-LGBTI cases. I do not categorically define emotions nor do I exhaustively try to document how they manifest in law. Rather, I register the enactment of specific emotions. Drawing from Sara Ahmed, this register takes emotions in terms of their textual features: they animate legal ideas and shape social norms in judgments. ${ }^{31}$ These emotional enactments arise from the contact between objects. $^{32}$ To read emotion, I follow the contact between objects (such as doctrines, facts, and norms) that shape queer injuries, intimacies, and identities and the remedies deemed to address or repair them. Attending to case law in terms of these contact zones, by focusing on their enactments, helps to expose legal biases and (hetero)normative limits they give effect to. ${ }^{33}$

Reading emotion as a scholarly strategy is a form of activist engagement. ${ }^{34}$ Using emotion as an analytic framework to engage with pro-LGBTI cases allows us to register the particular ways these cases recognise queer injury, intimacy, and identity and this enables us to navigate the legal and social consequences of these forms of recognition. As Kenji Yoshino argues, in relation to sexual minorities, ideas of gay visibility cannot be reduced to who is 'in' or 'out' of the proverbial closet. Rather, social norms allow sexual minorities to express some forms of their sexuality in public while urging them to 'cover' more discomforting aspects of their sexual life. ${ }^{35}$ Borrowing from Yoshino's idea of covering in relation to sexual minorities, I argue that emotional norms in case law that enable new forms of individual recognition and visibility can work, paradoxically, to cover over other institutional forms of injury, intimacy, and identity. While this paper speaks to the institutional possibilities of better judgments, my purpose when reading emotion is to primarily account for the affective reasons of jurisprudential recognition in pro-LGBTI cases without critiquing all emotions or offering emotion as a prescription for securing LGBTI human rights. This focus is significant for queer activist legal scholars who seek to further legal projects concerned with human rights agendas while maintaining a deeper, critical, and affective engagement with the terms of those agendas. In the following sections, I want to show that using emotion as an analytic lens allows us, as activist legal scholars, to more richly register the consequences of 'progress' in order for us to explore or critique the affective trouble queer injury, intimacy, and identity pose in cases concerned with healing hate and liberating love.

\section{Healing hate and hate crime jurisprudence}

In order to tease out how we can read emotion in pro-LGBTI cases, I now turn to the way criminal law functions to address queer injury through the Hate Crimes Prevention Act of 2009 and associated jurisprudence in the US. Specifically, the marking out of identity differences, acts of injury, and the intimacy between victims and offenders, is key to the construction of hate in pro-LGBTI criminal law reform. In recent decades, the recognition of homophobic and transphobic violence has precipitated public demands for criminalisation to deal with what is often colloquially referred to as 'hate crimes'. This demand reflects a remarkable shift in the positioning of queer bodies in the criminal law: homosexual criminalisation is replaced by a criminalisation of (some) homophobes. The 
violent homophobe is a queer body because they disturb a social order purporting to 'tolerate' sexual difference. Like the formerly criminalised homosexual, criminalised homophobes act in ways that cannot be socially assimilated. As Ely Aharonson observes, this shift towards criminalisation is about citizenship: hate crimes are imagined as a threat to the state's interest in equality, and thus 'pro-minority criminalisation' becomes a strategy for reasserting ideals of egalitarian citizenship. ${ }^{36}$ Communities, in addition to individual citizens, are seen as injured by hate crimes.

In the US, following the brutal murders of James Byrd Jr. and Matthew Shepard, there was overwhelming activist mobilisation demanding federal penalties for racist and homophobic violence. ${ }^{37}$ It is important to note that while the US Congress had previously enacted the Hate Crimes Statistics Act of 1990, the federal impetus to investigate hate crimes was limited to data collection rather than individual prosecutions (as the acts in question were otherwise criminal already). Such legislation was subject to enormous critique for its discretionary application and lack of punitive effects. ${ }^{38}$ The legislation also failed to account for gender-identity-motivated violence. Hate crime was being recorded, but little was being done at a federal level to prevent it. Legislation was introduced following those two highly publicised homicides as an attempt to supplement the perceived statutory deficiencies. ${ }^{39}$ Former US President Barack Obama, in commemorating the enactment of the Hate Crimes Prevention Act, emphasised that 'no one in America should ever be afraid to walk down the street holding the hands of the person they love'. ${ }^{40}$ He continued, 'we must stand against crimes that are meant not only to break bones, but to break spirits'. ${ }^{41}$ Here, love and hope were invoked to 'stand' against the fears and injuries generated by hate crime.

Reading this presidential pronouncement affectively, we can observe how the claim to optimism and futurity marks a contrast to the treatment of homosexuality as threat. Instead of (partially) locating responsibility for death on the victim's sexually assertive or 'threatening' behaviour, hate crime laws work to refuse what Obama referred to here as the crimes that 'break spirits'. Obama invoked hate crime law as both the recognition of the 'seriousness' of such violence and the remedy capable of 'healing' insecurity within the community (in this instance, the gay and lesbian community). Obama's celebration of hate crime legislation operated at the level of metaphor: non-heterosexuality was particularised through sentimental and uncontroversial tropes such as love and 'holding hands'. The non-explicit intimate bonds between two people were marked out as worthy of protection. In other words, queers who love by exhibiting romantic intimacies or domesticated identities were to be protected from the brutality of injury.

Criminalising hate crime requires more than holding individual offenders accountable for ill feeling or acts of violence. Legislative responses seek to secure the civil rights of subordinated groups through punitive sanctions directed against violent bigots. They signify a number of emotional investments primarily by invoking a public urgency to address homophobia and restore social order. ${ }^{42}$ In the Hate Crimes Prevention Act, the 'findings' preamble notes that hate crime 'disrupts the tranquillity and safety of communities' ${ }^{43}$ The findings also go on to state that such violence 'devastates not just the actual victim and the family and friends of the victim, but frequently savages the community sharing the traits that caused the victim to be selected'. ${ }^{44}$ The legislation purports to recognise the intimate associations between the victims, their families, and the broader community to which the victims belong. In doing so, it imagines the national community as 
tolerant and inclusive and casts those who would be liable under the Act as violent interlopers in the community.

This is a process in which homophobes, instead of homosexuals, are made queer (in the sense that they are socially deviant) to the community. In discussing the Hate Crimes Prevention Act, Obama's analogising of hate crime with 'savagery' stigmatised offenders as barbaric or uncivilised, while his comments sentimentalised the community as a homogenous site of 'tranquillity'. In sentimentalising the community as always already safe and welcoming, Obama deemed those who expressed violent homophobia as lacking self-control. These individuals became emotionally aberrant by virtue of their savage ill feeling towards homosexuality, and that ill feeling threatened an otherwise tranquil community. In Bennett $v$ Texas (1992), for example, the defendant appealed his sentence for murdering a gay man on the basis that it was excessive. On appeal, Barajas J affirmed the trial decision, noting that the 'excessive' violence (in this case, anal injuries) was punished with a term of incarceration of 60 years - a sentence held appropriate rather than excessive. ${ }^{45}$ While the case predated the existence of specific hate crime legislation, it is interesting to note how excessive violence was construed as disruptive to the social order and needed to be contained through enhanced (but legally appropriate) penalties. By redirecting hostility from the victim to the perpetrator, Bennett showed how homophobia was relatively easy to delineate when described in terms of a single offence and offender.

However, these emotional enactments do not correspond with material change. Symbolic references in pro-LGBTI hate crime cases to both violent excess and calculated sentencing place greater emphasis on the criminal law rationale of individual responsibility, rather than taking account of different political and social structures of subordination. ${ }^{46}$ The Hate Crimes Prevention Act positions homophobic violence (among other forms of minoritarian identity-based violence) as something antithetical to a national order, rather than as a phenomenon implicated directly within it. ${ }^{47}$ The exceptionalism invoked in legal responses to hate crime is important to note because we must consider the symbolic effects of hate crime legislation and the excessive violence that it enacts. The Hate Crimes Prevention Act institutes assumptions that homophobes are both 'wilful' and exceptional in the community.

The emotional interests of the state in delineating definitional narrowness for hate crime laws are privileged over the queer experiences of both perpetrators and victims of homophobic and transphobic violence. By transposing my earlier political discussion of the Hate Crimes Prevention Act into the judicial arena, we can observe how the legislation has criminalised wilful bodily injury (and death) because of the victim's actual or perceived sexual orientation or gender identity. ${ }^{48}$ This hate crime law mobilises hostility against wilful offenders while leaving the social will untouched in terms of responsibility for queer exclusion. It is interesting to note the use of the word 'wilful' here - it designates wilfulness on the part of the individual or offender. The wilful offender is one who obstructs the harmonious social fabric by bringing social intolerance into the fold. ${ }^{49}$ In doing so, such offenders who hate (sexual minorities) are made inassimilable - queer to a purportedly tolerant society.

In the leading case upholding the validity of the law, Glenn $v$ Holder (2010), the US District Court refused standing to a conservative family association on the basis that causing 'headaches and stomachaches' to sexual minorities (a risk posed by the views 
that this group espoused) did not form a 'particular interest' that would generate a threat of prosecution under the Act. ${ }^{50}$ It is interesting to note that in opposing the legislation, the family association recognised the emotional dimensions of homophobic injury (including speech) - particularly ones causing bodily discomfort. While the Court upheld the validity of the federal hate crime statute, it did so noting that, for any federal prosecutions to succeed, federal authorities would need to demonstrate a malicious intent to cause bodily injury that excluded emotional shock or disorienting queasiness. Moreover, the judgment held that prosecutions must prove that the violence was attributable to a victim's (purported) sexual orientation or gender identity. Gwin J affirmed this position on appeal to the US Sixth Circuit Court of Appeals, where the majority held that the appellant's fear of prosecution for its views on homosexuality was misplaced. ${ }^{51}$ In fact, in a footnote, Gwin J held that the appellant had undertaken a 'tortured' reading of the Act. ${ }^{52}$ The Court's fleeting reference to pain worked to separate the 'less serious' forms of homophobic speech from the recognition of homophobic violence. While the appellant accepted that their homophobic speech was violent, the Court was quick to refuse that assertion to sustain the constitutional validity of the Act. Criminalising hate crime was given limited scope: it extended to intentional physical violence while expressly excluding pernicious forms of hate speech and other psychic injuries. ${ }^{53}$ Such queer references in the appellant's argument were dismissed in the appellate judgment. The Court privileged physical scars over emotional hurt when it came to recognising injury.

Despite the casual tendency to refer to homophobic violence as necessarily a hate crime, a number of legal commentators have expressed caution regarding the conceptual 'cleanliness' of, and the vociferous demand to use, the term. As James Jacobs and Kimberley Potter argue, reading anti-gay violence by reference to a causal explanation of individual hatred confuses the complex interaction of opportunities and institutions. ${ }^{54}$ The emphasis on hate alone tends to obscure the complex economy of emotions: the violence produces identities of vulnerability by spreading intimidation and fear to those who identify with the social position of the victim.

These emotions become more apparent in institutional support. For example, the failure to appreciate this emotional point was illustrated in United States $v$ Jenkins (2012), where Van Tatenhove J held that 'there is no significant economic market for bias motivated crime'. ${ }^{55}$ While the reasoning in the case concentrated on the constitutional validity of using the commerce clause to criminalise hate crime federally, his point affirmed the way in which hate crimes were read as individual acts of aberrant violence rather than as an institutionally entrenched (in this case economic) phenomenon. Hate crimes may be socially injurious, but the responsibility for such injuries lay with individual rather than other institutional actors. In this case, the Court held that the Hate Crimes Prevention Act must be expressed in a 'limited fashion' to avoid overreaching into state jurisdiction. ${ }^{56}$ Hate crime violence was localised to mean physical acts that were, in some way, detrimental to federal commerce.

We can describe the emotional economies of victimhood and offending in pro-LGBTI hate crime cases quite simply: the pitied victimised queer object has its value pitted against the hated homophobic object, and the law works as the instrument to emotionally measure the value of both objects. Bringing together the jurisprudence surrounding the Hate Crimes Prevention Act with a broader public insistence on criminalising homophobic 
and transphobic violence, we can observe how hate crime functions as a moral category that generates 'emotional thinking' among the public as part of a call for social justice. ${ }^{57}$ Legal interventions directed at punishing homophobic and transphobic violence become a/ effective 'morality plays' that involve rejecting the injurious prejudice exhibited by offenders and respecting the intimacy and identity of the victims. ${ }^{58}$ In particular, the labelling of violence as a hate crime is contingent on the capacity to recognise the hate of perpetrators while generating compassion or pity for the victim who is subject to such hate. ${ }^{59}$ Obama's words welcoming the Hate Crimes Prevention Act are apt here: 'we sense where such cruelty begins ... the moment we fail to see in another our common humanity'. ${ }^{60} \mathrm{Com}$ passion becomes a key emotional enactment for securing moral claims for respect and recognition. Victims must be palatable objects amenable to becoming the subject of sentimental narratives involving a 'common humanity' in order to garner support. ${ }^{61}$ The characterisation of a particular act of injury as a hate crime is 'compelled' by the extent to which perpetrators and victims can subscribe to social archetypes and generate the emotional resonances stereotypically associated with their respective identities. Hate crimes and the judicial responses that deal with them perform a public theatre involving claims for inclusion and recognition. Neither victim nor perpetrator can be too queer or they risk being (emotionally) excluded from the narrative.

In this context, it becomes apparent how emotions serve as the anchoring points for legislative and political visibility. In contrast to laws criminalising sodomy, pro-LGBTI hate crime cases redirect the meanings of criminality, anxiety, and deviance from homosexuals to homophobes. ${ }^{62}$ Yet, the progressive emotional redirection in cases such as Glenn and Jenkins relied on a personalising narrative of hate that limited the scope for recognising the banal institutional entrenchment of homophobia. Accommodating queer claims for inclusion relied on personalising homophobic hatred and its remedies, rather than reshaping existing institutional practices. Hate crime laws may render queer victims visible and punish anti-queer offenders, but they do so at a cost - the covering over of institutional accountability.

Judicial decisions (when giving effect to particular statutes) play an instrumental role in emotionally construing homosexuality in contradictory ways. Queers can be rendered objects of scorn, revulsion, and/or pity for the public. The Hate Crimes Prevention Act recognises homophobic and transphobic injury insofar as it results in a 'bodily injury' defined against psychic or identity traumas. The preambular references to 'free speech' in the legislation work to disassociate homophobic and transphobic violence from hateful speech. The law maintains certain kinds of homophobic and transphobic injuries (verbal taunts and psychological damage) and disregards them in its attempt to remedy or eradicate them. By enacting hate in pro-LGBTI cases, as referenced in the Hate Crimes Prevention Act and associated jurisprudence, the state is able to exhibit a formal condemnation of homophobic and transphobic injury - while covering structural aspects of its existence. For activist legal scholars wishing to counteract the impacts of homophobia, reading emotion offers a way to register the socio-legal consequences of hate crime law while reflecting on whether the pursuit of heightened criminal penalties will secure the safety of queer minorities and/or minimise the ways the state participates in the marginalisation of queers. This approach does not abandon activist demands to hold homophobes accountable for violence but rather provides a lens to navigate how those demands are emotionally articulated through progressive jurisprudence. 


\section{Liberating love and marriage equality jurisprudence}

In contrast to criminal law and the enactment of hate to punish homophobes, LGBTI people have simultaneously turned to constitutional law to affirm their intimacies and identities. Marriage, in particular, is prized as the ultimate affirmation of social inclusion. ${ }^{63}$ In taking this further, I want to look at how pro-LGBTI marriage equality cases enact love to circumscribe legal recognition in problematic ways. California offers us a rich example of this. California's move towards marriage equality began in 2004. Following the legalisation of marriage equality in Massachusetts, San Francisco Mayor Gavin Newsom ordered that county clerks issue same-sex couples with marriage licences. ${ }^{64} \mathrm{~A}$ few years earlier, the California Family Code had been amended by a public ballot to restrict the definition of marriage to opposite-sex couples. Newsom believed, however, given the outcome in Massachusetts, that such a ban was inconsistent with California's (similarly drafted) state constitution. In response, he opened up the city to solemnising same-sex marriages. Same-sex couples flocked from around the state (and from other parts of the country) to get married. Within weeks, the Supreme Court of California nullified the marriages that had taken place. $^{65}$

Bolstered by the promise of love (alongside desires for equality), the lead plaintiff couples and the City of San Francisco sought a declaration that the statutory definition of marriage breached the liberty and equality guarantees of the state's constitution. ${ }^{66}$ The In Re Marriage Cases consolidated six appeals from various couples across the state. At the California Court of Appeal, the claims were dismissed on the basis that the gender-specific marriage laws were 'rationally' enacted and there was no 'fundamental right' to a same-sex marriage. In delivering the majority opinion, McGuiness PJ subordinated private expressions of love to the 'public role' marriage played in 'organizing fundamental aspects of our society'. ${ }^{67}$ Denying same-sex marriage was not a denial of privacy, but rather amounted to a rational decision by the public to preserve the institution for its traditional procreative purposes. ${ }^{68}$ Rather than consider the issue as one of (denying) liberty, the majority focused on the unique institutional features of marriage to justify exclusion.

Moreover, in the California Court of Appeal, love and privacy were decoupled from marriage and publicity, respectively, to distinguish same-sex and heterosexual forms of love. The Court held that same-sex couples were not seeking to end government interference or criminalisation; they were aspiring for government imprimatur of their intimacies. $^{69}$ That was not a constitutional issue of privacy or liberty, but one of permissible 'state interests'. If same-sex marriage was to become legal, the issue needed to be decided by the people and their elected representatives - not the courts. ${ }^{70}$

In the dissent, however, marriage was cast as a love of liberty (not just of a partner). Kline J, in dissent, held that pursuing marriage was a 'self-defining' feature of personal integrity. Kline J refuted the majority's framing of privacy and forcefully argued for a more expansive view of privacy that encompassed the intimacy of same-sex couples. Kline J held:

The marital relationship is within the zone of autonomy protected by the right of privacy not just because of the profound nature of the attachment and commitment that marriage represents, the material benefits it provides, and the social ordering it furthers, but also because the decision to marry represents one of the most self-defining decisions an individual can make. ${ }^{71}$ 
In Kline J's account, marriage not only ordered intimacy, but also provided the basis through which individuals could define their identities. The private and public blurred together: personal attachment and commitment could be publicly recognised both materially and socially. By denying same-sex couples the right to pursue marriage, the state interfered with the private expression of intimacy. Marital exclusion was an arbitrary state obstacle to couples seeking to express love. Moreover, treating expressions of same-sex love (such as declarations of commitment or decisions to have children) as different from heterosexual love for the purpose of public regulation suppressed individuals' public expression. ${ }^{72}$ Children also figured in this expression of ordered liberty. Denying children the formality of married parents perniciously impacted on their lives by disallowing their families the social and legal security of marriage.

The Court of Appeal's decision was overturned on appeal to the California Supreme Court. Kline J's dissent about the connections between liberty, love, and family was more favourably received than the majority's holding about the 'rational basis' of 'traditional marriage'. George CJ concluded:

In view of the substance and significance of the fundamental constitutional right to form a family relationship, the California Constitution properly must be interpreted to guarantee this basic civil right to all Californians, whether gay or heterosexual, and to same-sex couples as well as opposite-sex couples. ${ }^{73}$

In the California Supreme Court, liberty was tied to intimacy: a right to formulate relationships. The Court refused to distinguish privacy and kinship. ${ }^{74}$ The autonomy to form a family was blocked by the state's refusal to grant a marriage licence. Marriage was not a privilege granted by the government but a civil right mandated by the Constitution. Yet, the continued invocation of family was also used to sustain the intimacy between liberty and living well. In particular, marriage was not simply a subpart of the right to intimate association. ${ }^{75}$ Rather, it remained an opportunity to be recognised 'with a loved one' that was of the 'deepest and utmost importance' to the individual or couple. ${ }^{76}$ Such liberty was about securing love.

Loving liberty secured loving same-sex intimacies. In bringing together liberty and intimacy, George CJ held that marriage afforded the plaintiffs an 'opportunity to live a happy, meaningful, and satisfying life as a full member of society'. ${ }^{77}$ By enacting marital love in terms of wellbeing and satisfaction, marriage accrued value by enabling the liberty of those seeking access to the institution. This also had a productive potential: it channelled same-sex intimacies from the injury of exclusion into satisfying partnerships. While the majority opinion in the case eschewed the contention that marriage could be restricted to a 'responsible' reproductive purpose, the claim of love (re)enacted in this case rendered marital love synonymous with the notion of relationship stability. Liberty was invoked through love to help overturn the statutory bar on same-sex marriage. While hate consigned homophobes to criminality, love badged gay relationships with respectability.

Following the decision of the California Supreme Court, a number of groups petitioned the state to give the public the final say on same-sex marriage by subjecting it to a popular vote. Dubbed Proposition 8, an amendment was put at the 2008 election to constitutionally define marriage as the union between a man and a woman. ${ }^{78}$ Both sides, in a vicious public campaign, spent millions of dollars to sway Californian voters. Proposition 8 passed 
narrowly, with $52 \%$ of the public vote. Proponents of the measure were successful largely by framing the issue in terms of (threats to) children: 'We should not accept a court decision that may result in public schools teaching our own kids that gay marriage is ok' ${ }^{79}$ The amendment created a precarious legal environment for same-sex couples in the state. As the amendment was designed to have only prospective effect, the 18,000 same-sex marriages solemnised prior to its passage remained valid. Yet, same-sex couples were now unable to get married. This created a situation where some same-sex relationships were recognised as marriages, while others were not.

Divergences in recognition prompted an immediate challenge on procedural grounds relating to the constitutional amendments. These appeals were dismissed on the basis that the Constitution was validly amended by a proper process. ${ }^{80}$ This then led to a challenge on federal constitutional grounds in Perry $v$ Schwarzenegger (2010). This case involved a group of same-sex couples (who came from different cultural backgrounds and had been together for different lengths of time) to resolve a constitutional question: did the bar on same-sex marriage violate the Due Process Clause of the Fourteenth Amendment of the US Constitution? ${ }^{81}$

At trial, the plaintiffs testified about what marriage meant to them as a matter of love. Lead plaintiff Sandy Stier distinguished between domestic partnerships and marriage:

There is certainly nothing about domestic partnership as an institution - not even as an institution, but as a legal agreement that indicates the love and commitment that are inherent in marriage and [domestic partnership] doesn't have anything to do for us with the nature of our relationship and the type of enduring relationship we want it to be. ${ }^{82}$

Stier's plea for recognition concentrated on the liberty to define the relationship in the terms that she (and her partner) deemed appropriate. The term 'domestic partnership' may have offered equivalent legal benefits, but it was not imbued with the love and commitment that were promised by marriage. The enactment of love - realised in an enduring relationship - was the main reason why the plaintiffs sought (and were granted) injunctive relief from the Court against Proposition 8: they wanted the liberty to proclaim their love.

Marital love also created a sense of 'weightiness' to legal recognition. Walker CJ found that the denial of same-sex marriage interfered with the right to intimate expression. As a matter of law, neither side contested the idea that marriage was a 'fundamental right' ${ }^{83}$ Rather, the dispute hinged on what characteristics made the right fundamental. Drawing on the language from the California Supreme Court's earlier decision in the In Re Marriage Cases and expert testimony provided to the Court, Walker CJ held that same-sex couples were 'identical' to their opposite-sex counterparts when it came to forming 'deep emotional bonds and strong commitments' ${ }^{84}$ Legal recognition of samesex marriage, therefore, provided an additional dimension of legitimacy and integration to existing cultural practices (such as same-sex commitment ceremonies). Same-sex couples were not seeking to acquire a new right; they were merely asserting their existing right to marry a partner of their choice. By making this claim, Walker CJ used love to show that marriage could not rationally be considered a gendered issue. Yet, while the foundations of marital love were no longer gendered, the worthiness of its foundations as a 'shiny' or noble expression of intimacy remained uncontested.

Marriage equality is a powerful love story - one that the Californian courts scripted through a plot of order, maturity, and commitment. Unlike pro-LGBTI hate 
crime cases that work to police (homophobic) subjects, pro-LGBTI marriage equality cases seek to privilege the intimacies of (gay) subjects. As Walker CJ held in Perry, marriage provided a social order through which same-sex couples could find love from 'deep emotional bonds' and 'strong commitments' ${ }^{85}$ Love made way here for couples that had their ability to express such commitment blocked by gendered definitions of marriage.

Insidiously, these enactments of love work to police queer intimacies. As Casey Charles notes, queers have survived by protesting reproductive sexual assimilation. ${ }^{86}$ Mutually supportive communities and associations have been encouraged (in varied erotic, intergenerational, caring, platonic forms) over recognition that privileges the couple as the primary vehicle for recognising intimacy. ${ }^{87}$ In Perry, Sandy Stier invoked love as the means by which to claim the right to 'self-define' her relationship with her partner, Kristin Perry. ${ }^{88}$ The Court's love of liberty - as a principle central to US constitutionalism - granted her that right. Law had the power to provide a (marital) way for people to determine their happy endings. Yet, reading pro-LGBTI marriage equality cases in a register of emotion can expose their inability to liberate self-defining intimacies that disrupt enactments of love that centre on notions of monogamy and fidelity. In Why Love Leads to Justice, David Richards argues that love creates a 'resisting voice' to free us from the oppressive force of patriarchy. ${ }^{89}$ By loving across racial and gendered boundaries, he notes that we can free ourselves from the 'moral slavery' of norms and institutions that deny us our autonomy and integrity. ${ }^{90}$ However, as my reading of pro-LGBTI marriage equality cases cautions, love can create an 'affective slavery' - where love works to bind same-sex couples into specific heteronormative fantasies of constitutional liberty. Marriage becomes a pairing of two people who purportedly commit by forsaking all others. The push to exclude others from marriage (such as those in non-dyadic relationships) was an act of subordination and non-recognition. ${ }^{91}$ By distinguishing polyamory (and polygamy) from marriage equality, these cases closed off the purported 'slippery slope' invoked by opponents. ${ }^{92}$ Put simply, the love to affirm and maintain an exclusive commitment with one person evident in Perry and In Re Marriage Cases $(2006,2008)$ was distinct from the desire to marry multiple people. Love did not cross boundaries. Instead, it solidified intimacy into a pair. Here, I would add that non-recognition is an emotional matter of law: queer intimacies that disturb, disgust, or threaten the loving definitions' of marriage (such as polygamy or promiscuity) are covered over in the same moment that the doctrinal definitions are partially opened up to affirm loving same-sex couples.

By attending to emotion - registering the enactments of love - activist legal scholars can observe how courts circumscribe the limits of what love makes possible in terms of legal recognition of same-sex relationships. Jurisprudential claims of love cover over the ways in which the state marginalises queers. Making this visible is critical at a time when activists and lawyers turn to courts to secure greater liberties. By taking account of how love functions to shape a specific idea of kinship, activist scholars can pause to reflect on the queer intimacies erased by such enactments of love. This does not require us to abandon marriage equality as a way to provide rights and recognition to same-sex couples. However, reading emotion allows us to emotionally (re)think how we advance claims for relationship recognition and makes space for queer intimacies that do not conform to existing (hetero)normative legal formulations of love. 


\section{Conclusion}

Activist legal scholars animated by claims for queer justice must register emotion in jurisprudential claims of progress. By reading emotion, this paper does not suggest that courts let go of their responsibilities to adjudicate, or that the law remove itself from attempting to remedy queer exclusions. Taking emotion seriously in activist legal scholarship is not about choosing sides among activists who condemn the law, those who urge us to embrace it, or even those who sit in between this ever-expanding spectrum of opinions (after all, existing activist legal scholarship does not sit in neat binaries). Instead, my reading in a register of emotion, borne through an exploration of US hate crime and marriage equality jurisprudence, exposes what is made visible and what is covered over in proLGBTI cases that purport to repair queer injury and further queer intimacy and identity. In the pursuit to criminalise and punish violent homophobes, pro-LGBTI hate crime cases risk covering the emotional, as well social, conditions that make queer injury possible. Alternatively, pursuits to anchor love to relationship recognition produce sentimental formulations of kinship that risk covering over transient, abject or socially unproductive queer intimacies and identities.

By analysing queer injury, intimacy, and identity in two different sites of pro-LGBTI cases, this paper has shown how both hate crime and marriage equality jurisprudence in the US has worked to deny the recognition of those who were emotionally queer to a legal order that sustained certain emotional sentiments (such as the 'homophobic hater' or 'loving couple'). In other words, the emotional enactments in each area of jurisprudence allowed certain forms of queer injury, intimacy, or identity to be made visible while also covering over more structural or sustained forms of exclusions that queers faced on a daily basis.

Reading emotions as legal enactments better equips us, as activist legal scholars, to address their socio-legal consequences in progressive activist agendas. We do not have to expel or embrace emotion (as if either were possible) in law to further the rights of LGBTI people. Rather, we must contend with emotion in our pursuits of recognition. This is not limited to LGBTI issues. Using emotion to queer progress will also enable activist-scholars in other areas to expose the insidious consequences of law reform and nuance our responses to emotion when seeking to advance the rights of minorities through law.

\section{Notes}

1. This is a rich body of literature. I take inspiration from critical race and feminist scholarship, See Kimberle Crenshaw, 'Race, Reform, and Retrenchment: Transformation and Legitimation in Antidiscrimination Law', Harvard Law Review 101, no. 3 (1988): 1331-87; Kimberle Crenshaw, 'Mapping the Margins: Intersectionality, Identity Politics, and Violence Against Women of Colour', Connecticut Law Review 43, no. 5 (1991): 1241-99; and Mari Matsuda, 'Looking to the Bottom: Critical Legal Studies and Reparations', Harvard Civil Rights-Civil Liberties Law Review 22 (1987): 323-99.

2. Frank Munger, 'Inquiry and Activism in Law and Society', Law \& Society Review 35 (2001): 9.

3. Jane Schacter, 'Sexual Orientation, Social Change, and the Courts', Drake Law Review 54 (2005): 863.

4. Ibid.

5. Yvonne Zylan, States of Passion: Law, Identity and the Social Construction of Desire (Oxford: Oxford University Press, 2000), 5. 
6. Chris Ashford, 'Sexualities and the Law', Sexualities 14, no. 3 (2000): 265.

7. Lisa Bower, 'Queer Acts and the Politics of Direct Address: Rethinking Law, Culture and Community', Law \& Society Review 28, no. 5 (1994): 1010.

8. Ruthann Robson, 'Judicial Review and Sexual Freedom', University of Hawai'i Law Review 30 (2007): 46.

9. Darren Hutchinson, 'The Majoritarian Difficulty: Affirmative Action, Sodomy, and Supreme Court Politics', Law and Inequality 23 (2005): 29-30.

10. John Fisher, 'Outlaws or In-laws? Successes and Challenges in the Struggle for LGBT Equality', McGill Law Journal 49 (2003): 1190-2.

11. Ibid., 1993-4.

12. Leslie Moran, 'What Kind of Field Is "Law, Gender and Sexuality"? Achievements, Concerns and Possible Futures', Feminist Legal Studies 17 (2009): 309-13.

13. Marc Spindelman, 'Sexuality's Law', Columbia Journal of Gender and Law 24, no. 2 (2013): 87.

14. Ibid., 103.

15. Joey L. Mogul, Andrea Ritchie, and Kay Whitlock, Queer (In)Justice: The Criminalization of LGBT People in the United States (Boston, MA: Beacon Press, 2011), xviii.

16. Lauren G. Berlant and Michael Warner, 'Sex in Public', in Intimacy, ed. L. Berlant (Chicago, IL: Chicago University Press, 2000), 322.

17. Aleardo Zanghellini, 'Queer, Antinormativity, Counter-Normativity and Abjection', Griffith Law Review 18, no. 1 (2008): 4.

18. Robert Lecky, 'Introduction: After Legal Equality', in After Legal Equality: Family, Sex, Kinship (London: Routledge, 2015), 12.

19. Ryan Thoreson, Transnational LGBT Activism: Working for Sexual Rights Worldwide (Minneapolis, MN: Minnesota University Press, 2014).

20. Schacter, 'Sexual Orientation, Social Change', 861-93.

21. Judith Butler, 'Against Proper Objects', differences: A Journal of Feminist Cultural Studies 6 (1994): 4.

22. Robyn Wiegman, Object Lessons (Durham, NC: Duke University Press, 2012), 4.

23. Fleur Johns, 'On Writing Dangerously', Sydney Law Review 26 (2003): 473.

24. Ibid., 475 .

25. Ibid., 479 .

26. Kathryn Abrams, 'Seeking Emotional Ends with Legal Means', California Law Review 103 (2015): 1670.

27. Arlie R. Hochschild, The Managed Heart: Commercialization of Human Feeling (Berkeley, CA: University California Press, 1983); Terry Maroney, 'Law and Emotion: A Proposed Taxonomy of an Emerging Field', Law and Human Behaviour 30 (2006): 119-42; Eric Posner, 'Law and the Emotions', Georgetown Law Journal 89, no. 6 (2001): 1977-2012.

28. James B. White, Heracles' Bow: Essays on the Rhetoric and Poetics of the Law (Madison, WI: University Wisconsin Press, 1985), xi.

29. Duncan Kennedy, 'Freedom and Constraint in Adjudication: A Critical Phenomenology', Journal of Legal Education 36 (1986): 518-62. Kennedy provides a phenomenological account of judicial decision-making.

30. Eve Sedgwick, Touching Feeling: Affect, Pedagogy, Performativity (Durham, NC: Duke University Press, 2003), 135-6.

31. Sara Ahmed, The Cultural Politics of Emotion (New York, NY: Routledge, 2004), 5.

32. Ibid., 5 .

33. Sara Ahmed, Queer Phenomenology: Orientations, Objects, Others (Durham, NC: Duke University Press, 2006), 23. This approach dovetails with 'frame analysis' in social movement scholarship, which seeks to understand symbolic meanings generated through social justice claims. See David A. Snow and Catherine Corrigall-Brown, 'Falling on Deaf Ears: Confronting the Prospect of Nonresonant Frames', in Rhyming Hope and History: Activists, Academics, and Social Movement Scholarship, ed. D. Croteau, W. Hoynes, and C. Ryan (Minneapolis, MN: University of Minnesota Press, 2000), 222-39. 
34. I share Richard O. Lempert's view that scholarship can be a form of activism by generating new ideas to challenge injustice. See Richard O. Lempert's, 'Activist Scholarship', Law \& Society Review 35 (2001): 26.

35. Kenji Yoshino, 'Covering', Yale Law Journal 111, no. 4 (2002): 837.

36. Ely Aharonson, "Pro-Minority" Criminalization and the Transformation of Visions of Citizenship in Contemporary Liberal Democracies: A Critique', New Criminal Law Review 13, no. 2 (2010): 289.

37. Bernard Haggerty, 'Hate Crimes: A View from Laramie, Wyoming's First Bias Crime Law, the Fight against Discriminatory Crime, and a New Cooperative Federalism', Howard Law Journal 45 (2001): 1-75. Matthew Shepard was a young gay man who was murdered by Aaron McKinney and Russell Henderson. McKinney and Henderson tortured Shepard, tied him up, and then left him to die on a fence in a remote area near Laramie.

38. James Jacobs and Kimberley Potter, 'Hate Crimes: A Critical Perspective', Crime \& Justice 22 (1997): 1-50.

39. 18 USC $\$ 249$.

40. White House Press Release, 'Remarks by the President at Reception Commemorating the Enactment of the Matthew Shepard and James Byrd, Jr. Hate Crimes Prevention Act' (October 28, 2009), http://www.whitehouse.gov/the-press-office/remarks-president-reception-commemora ting-enactment-matthew-shepard-and-james-byrd- (accessed August 5, 2016).

41. Ibid.

42. Leslie Moran, 'The Emotional Dimensions of Lesbian and Gay Demands for Hate Crime Reform', McGill Law Journal 49 (2004): 928-9.

43. See note 32 .

44. Ibid.

45. Bennett $v$ Texas, 831 SW 2d 20 at 22 (1992), 22.

46. Morris Kaplan, 'Hate Crime and the Privatization of Political Responsibility: Protecting Queer Citizens in the United States?', Liverpool Law Review 29 (2008): 40.

47. See note 42 .

48. Ibid.

49. Sara Ahmed, Willful Subjects (London: Duke University Press, 2014), 42.

50. Glenn v Holder, 738 F Supp $2 \mathrm{~d} 718$ (2010), 21.

51. Glenn v Holder, 690 F 3d 417 (2012), 425.

52. Ibid., 427.

53. Glenn (2010), 24.

54. Jacobs and Potter, 'Hate Crimes', 2.

55. United States $v$ Jenkins, 909 F Supp 2d 758 (2012), 773.

56. Ibid.

57. Gail Mason, 'The Symbolic Purpose of Hate Crime Law: Ideal Victims and Emotion', Theoretical Criminology 18, no. 1 (2014): 76.

58. Gail Mason, 'Not Our Kind of Hate Crime', Law and Critique 12 (2001): 255.

59. Ibid.

60. White House Press Release, 'Remarks by the President'.

61. Mason, 'The Symbolic Purpose of Hate Crime Law', 80-2.

62. Stephen Tomsen, Violence, Prejudice \& Sexuality (New York, NY: Routledge, 2009), 46.

63. See for example Nancy D. Polikoff, Beyond (Straight and Gay) Marriage: Valuing All Families under the Law (Boston, MA: Beacon Press, 2008).

64. In Re Marriage Cases 49 Cal.Rptr.3d 675 (2006), 685.

65. Lockyer $v$ City and County of San Francisco 33 Cal.4th 1055 (2004).

66. In Re Marriage Cases (2006), 687.

67. Ibid., 715 .

68. Ibid., 719 .

69. Ibid., 723 .

70. Ibid., 730 .

71. Ibid., 736 . 
72. Ibid., 744, 749 .

73. In Re Marriage Cases 43 Cal.4th 757 (2008), 782.

74. Ibid., 814 .

75. Ibid., 782 .

76. Ibid., 818 .

77. Ibid., 820 .

78. Perry $v$ Schwarzenegger 704 F.Supp.2d 921 (2010), 928.

79. Ibid., 930.

80. Strauss $v$ Horton, $46 \mathrm{Cal} 4$ th 364 (2009).

81. Perry (2010).

82. Ibid., 939.

83. Ibid., 992.

84. Ibid., 967.

85. Ibid.

86. Casey Charles, Critical Queer Studies: Law, Film, and Fiction in Contemporary American Culture (New York, NY: Ashgate, 2012), 154.

87. Lauren G. Berlant, The Queen of America Goes to Washington City: Essays on Sex and Citizenship (Durham, NC: Duke University Press, 1997), 209.

88. Perry (2010), 939.

89. David Richards, Why Love Leads to Justice: Love across the Boundaries (Cambridge, Cambridge University Press 2016), 2.

90. Ibid., 25.

91. Polikoff, Beyond (Straight and Gay) Marriage, 108.

92. Courtney M. Cahill, “If Sex Offenders Can Marry, Then Why Not Gays and Lesbians?": An Essay on the Progressive Comparative Argument', Buffalo Law Review 55 (2007): 780.

\section{Disclosure statement}

No potential conflict of interest was reported by the authors.

\section{Notes on Contributor}

Dr Senthorun Raj is an academic lawyer/activist inspired by glitter, pop culture, and queer spaces. $\mathrm{He}$ is a Lecturer in Law at Keele University and Co-Director of the MA programme in Human Rights, Globalisation and Justice. Prior to this, he was a Scholar in Residence at New York University's Center for Human Rights and Global Justice and Senior Policy Advisor at the New South Wales Gay and Lesbian Rights Lobby. He also volunteers with various LGBTI advocacy and arts organisations. 